\title{
Up to date in inhalation anaesthesia: the desflurane
}

\author{
S Caroleo $^{1 *}$, O Bruno ${ }^{1}$, D Vuoto ${ }^{1}$, F Infelise ${ }^{1}$, A Renzulli ${ }^{3}$, E Santangelo ${ }^{2}$, B Amantea ${ }^{1}$ \\ From de Senectute: Age and Health Forum \\ Catanzaro, Italy. 5-7 December 2009
}

\section{Background}

The use of halogenated anaesthetics in cardiac surgery is still controversial. Preconditioning and postconditioning are the well described mechanisms that explain the protective myocardial effect of specific drugs in order to prevent the occurrence and/or to reduce the size of a necrotic post-ischemic myocardial area [1]: they play a well recognized role in the "protective effect" of the halogenated anaesthetics. Preconditioning and postconditioning protect the myocardial cell from oxidative stress and take place through the activation of specific receptors and second messengers systems [2]. Desflurane has shown a higher preconditioning and postconditioning power that could be optimal at $6 \%$ of Minimum Alveolar Concentration (MAC) [3]. The solubility of the halogenated anaesthetics can be altered during cardiac surgery: Desflurane has shown a rapid wash-in and wash-out profile in cardiac "on pump" surgery $[5,6]$.
2. Baines CP, Zhang J, Wang G-W, Zheng YT, Xiu JX, Cardwell EM, Bolli R, Ping P: Mitochondrial PKC $\varepsilon$ and MAPK from signaling modules in the murine heart. Circ Res 2002, 90:390-97.

3. Guarracino F, Landoni G, Tritapepe L, Pompei F, Leoni A, Aletti G, Scandroglio AM, Maselli D, De Luca M, Marchetti C, Crescenzi G, Zangrillo A: Myocardial damage prevented by volatile anesthetics: a multicenter randomized controlled study. J Cardiothorac Vasc Anaesth 2006, 20(4):477-83.

4. Zhou J, Lu J: Dynamic changes in blood Solubility of desflurane, isoflurane, and halothane during cardiac surgery. I Cardiothorac Vasc Anaesth 2001, 15(5):555-9.

5. Mets B, Reich NT, Mellas N, Beck J, Park S: Desflurane pharmacokinetics during cardiopulmonary bypass. J Cardiothorac Vasc Anaesth 2001, 15(2):179-82.

6. De Hert SG, Cromheecke S, ten Broecke PW, Mertens E, De Blier IG Stockman BA, Rodrigus IE, Van der Linden PJ: Effects of propofol, desflurane, and sevoflurane on recovery of myocardial function after coronary surgery in elderly high-risk patients. Anesthesiology 2004, 99(2):314-23.

doi:10.1186/1471-2318-10-S1-L56

Cite this article as: Caroleo et al:: Up to date in inhalation anaesthesia: the desflurane. BMC Geriatrics 2010 10(Suppl 1):L56.

\section{Conclusions}

Halogenated anaesthetics and especially desflurane protect myocardium from the peri-operative ischemic injury even in case of high risk elderly patients [7].

\section{Author details}

'Deparment of Anaesthesia and Reanimation, University of Catanzaro,

Catanzaro, Italy. ${ }^{2}$ Department of Anaesthesia and Oncological Intensive Care, Italy. ${ }^{3}$ Department of Cardiac Surgery, University of Catanzaro, Catanzaro, Italy.

\section{Published: 19 May 2010}

\section{References}

1. Murry CE, Jennings NB, Reimer KA: Preconditioning with ischemia: a delay of lethal cell injury in ischemic myocardium. Circulation 1986, 74:1124-1136.

Submit your next manuscript to BioMed Central and take full advantage of:

- Convenient online submission

- Thorough peer review

- No space constraints or color figure charges

- Immediate publication on acceptance

- Inclusion in PubIMed, CAS, Scopus and Google Scholar

- Research which is freely available for redistribution

Submit your manuscript at www.biomedcentral.com/submit
C Biomed Central 